\title{
Prospects and Challenges in Empowerment of Tribal Women
}

\author{
Ms. Swaleha Sindhi, \\ Assitant Professor, Department of Educational Administration, The M.S.University of Baroda. India
}

\begin{abstract}
Tribal development in India has been a success as the primitive societies living in remote rural areas are now educating their children and living in desirable standards. It is interesting to note that apart from several governmental efforts, the contributions of non-governmental organizations in providing training and development in different sectors of economy especially the tribal population. ERT India group initiated a survey as a part of the ERT International project to study the opportunities and avenues for the people living in remote tribal villages to acquire essential knowledge and skills for their livelihood. The project also focused on various skill development programs, especially for women. This paper discusses training as well as skills development in tribal women of Gujarat, India. The training and skill development among women would be mainly pertaining to farm forestry, papad making, sewing, cooking, sanitary pads making and so on. Women in tribal India often face abusive situations related to domestic violence, physical and mental torture, wife-beating, sexual abuse, and so forth. It is also realized that women face resistance in participating in training programmes due to sharing of responsibilities at family level. They also face barriers due to bias and discriminatory behavior common in society. Arrangements are made by the government and NGO'S to encourage women to form self-help groups and seek answers to their own problems. The paper brings out the cases of under-represented women who are successful in empowering themselves by making use of education and training. It reviews vocational and skill based training among the women of several tribal villages in Gujarat.
\end{abstract}

Key words: Empowerment of Tribal Women, Training and skills development.

\section{Introduction:}

India is a country of villages as the majority of its population lives in villages and far-flung remote areas. The interesting aspect is that every region of the country though connected with the cities now; however, still possesses its own peculiar traditional ethos. Also most of the rural communities/Tribal's are still devoid of modern facilities like education, electricity, proper drinking water, health care, ample transportation, etc. But the lack of education in many of the rural belts of India is proving fatal and acting as the breeding ground for social vices, evils and paving the way to anti-social/national activities.

Education enhances ones competence level to cope up better in physical and social environments, Bourdieu, an educational sociologist refers it to as cultural capital and argues that it is the dominant culture known as "cultural capital" because, via the educational system it can be translated into wealth and power, which rural community is usually devoid of despite possessing abundant resources and man power. It can transform the rural/tribal communities of India by: Ensuring the upward social mobility among people, by liberating them though slowly from the shackles of casteism, groupism and superstitious life ways. Further education will ensure opportunities for functional employment thereby empowering rural folk for more economic opportunities, growth and development and can thus lead to the change in the whole map of poor and downtrodden rural landscape.

This paper discusses the empowerment of tribal women in Gujarat through education and skill development as education, skills development and training are central to agricultural and rural employment especially the tribal's. It prepares mostly young people for work in the formal and informal sector in rural areas and thus plays an important role in poverty alleviation. The better the training and the more refined the skills in terms of human capital, higher the income and returns leading toward the better rural life and socio-economic structure. This goes without saying that India has the second largest tribal population in the world and its women continue to be under-represented in formal business training programmes thus limiting their employment options, economic returns and long term career development. Consequently, more disadvantaged, poorer and discriminated the women in any society, lesser the development index and poorer the growth and progress of that society. The fact is despite being unskilled, poor, suppressed or discriminated; women still try to contribute to family income either directly or indirectly. Poor and vulnerable women are usually more interested in skills training that meets their immediate 'practical gender needs' as opposed to longer term, "strategic gender needs" that directly tackle the basic underlying causes of female subordination (Moser:1989).

Women are often concentrated in handicrafts, basic food processing and sale which are traditionally considered to be women's domain. Women also show a propensity to pursue micro-enterprises and homestead farming activities (The World Bank, FAO, IFAD, 2008).Skills training, increased growth, productivity and 
innovation, in particular for the informal sector are linked with poverty reeducation.(Fluitman:2002). Skills development improves output, quality, diversity and occupational safety and improves health, thereby increasing incomes and livelihoods of the poor. It also helps to develop social CapitaLand strengthens knowledge about informal sector associations, rural organizations and governance. According to human capital theory, the better educated the agricultural labor, the higher their productivity (Atchoarena, et. al. 2003).

\section{Constitutional ${ }^{1}$ provisions of Tribal.}

The constitution has given more than 20 articles on the redressed and upliftment of underprivileged with policies on positive discrimination and affirmative action with reference to S.T.

- Article 14 confers equal rights and opportunities to all

- Article 15 prohibits discrimination against any citizen on the grounds of sex, religion, race, caste etc;

- Article 15 (4) States to make special provisions for advancement of any socially educationally backward classes;

- Article 16 (4) empowers the state to make provisions for reservation in appointments or posts in favour of any backward class of citizens, which in the opinion of state, is not adequately represented.

- Article 46 state to promote with special cares the educational and economic interests of the weaker section, especially the ST and protects the social injustice and all form of exploitation.

- Article 275 grant-in aid for promoting the welfare of ST and raising the level of administration

- Article 330 - Seats shall be reserved in the House of the People for -Article 332 Reservation of seats for Scheduled Castes and Scheduled Tribes in the Legislative Assemblies of the States 332,335 stipulates the claims that the members of the Scheduled Castes and the Scheduled Tribes shall be taken into consideration, consistently with the maintenance of efficiency of administration, in the making of appointments to services and posts in connection with the affairs of the Union or of a State.

- Article 244(1) tribal welfare communities to be setup for the welfare of the tribes.

- Article $22(2) 73^{\text {rd }}$ and $74^{\text {th }}$ amendments - to ensure effective participation of tribal in the process of planning and decision making.

- Extension to scheduled Areas Act 1996. Amendments of Constitution are extended to the Scheduled Areas through Panchayats.

These constitutional provisions of the Government of India helped in the development of the tribes and their education.

\section{The Prospect of the Tribal's of Gujarat \& Government's Initiatives:}

The State of Gujarat comprises of a total of 43 Talukas in 12 Scheduled Tribe dominant districts of total population, the population of scheduled tribes (ST also called 'tribal' and 'adivasi' ${ }^{2}$ ) is $15 \%$, i..e. about 75 lakhs. In Gujarat 28 scheduled tribes are enlisted and of them 8 are primitive tribes, mainly belong to Gir, Barda and Alech forests (mainly Junagadh and Jamnagar district in western Gujarat) and Ahmadabad district in central Gujarat. About 21 tribes are spread over 12 districts (north-eastern belt) in Gujarat. The major problems of the tribes in north Gujarat (Banaskantha, Sabarkantha,Panchmahal, Dahod and Vadodara) are - lower level of literacy, high incidences of sickle cell anemia, unemployment, high degree of migration and no access to forest or forest produce. The tribes of south Gujarat (Bharuch, Narmada, Surat, Tapi, Valsad, Navsari, Dangs districts) have reported higher level of literacy but they face similar set of problems, i.e. high incidences of sickle cell anemia, unemployment, high degree of migration and little access to forest or forest produce.

To ensure a better quality of life for the tribal population, the Constitution of India has advocated the policy of positive discrimination and affirmative action. For this purpose the Tribal Sub Plan (TSP) Strategy has been adopted for all round development of tribal areas since Fifth Five-Year Plan. Under the TSP approach, almost entire tribal inhabited area of Gujarat has been covered. Specially empowered Project Administrators have been appointed to carryout development programmes in these areas. The TSP approach ensures allocation of fund for tribal areas from State Plan in proportion to the ST population in the State. State of Gujarat had earmarked 15.85\% of its budget for the development of tribal areas during 2008-09.The Government of Gujarat has taken steps like launching Joint Forest management (JFM), Vanbandhu Yojana and such development programmes but its effect is limited in providing employment and better quality of life. Panchayati Raj

\footnotetext{
${ }^{1}$ The Constitution of India is the supreme law of India, containing 450 articles in 22 parts, 12 schedules and 94 amendments.
}

${ }^{2}$ Adivasi means Aboriginals or Native 
Extension to Scheduled Areas Act, 1998 (PESA) was expected to provide opportunity to tribal's for local selfgovernance but it has not been implemented by the government. In this situation, tribal development has remained centralized and largely government dependent. Unfortunately, the industrial houses have-not thought of engaging tribal educated youth meaningfully in respective units.

Towards accomplishment of the said objective and bringing qualitative change in the lives of tribal people, the State Government is implementing and further planning to implement several large scale projects with the help of commercial partners like private sector units, cooperative and public sector undertakings to double the income of ITDP talukas in next five years with the involvement of BPL families as major participants. This goal is now feasible due to enhanced funding under TASP, high economic growth rate of the State, increased opportunities in dairy, horticulture and service sectors, and involvement of private sector organizations on PPP model. Government has realized the need and importance of private sector participation in developmental activities for qualitative results.

\section{The Skill Development Initiative by the Tribal Development Department:}

Government of Gujarat is one of the Chief Minister's Ten Point Programmes to enable tribal people to upgrade their skills in order to get sustainable employment and thus increase their incomes. Skill development initiative includes various types of training programmes, involving both conventional and non-conventional subjects, varying in duration and cost. These training programmes are implemented through NGOs and institutions having expertise in their respective fields. With a view to understanding Training for aged tribal's especially women is emphasized in order to help them lead an independent and respectable life. As in any other case, tribal or not, aged women feel depressed and hence attention is given to them and are given proper medical aid, diet etc.

Tribal Welfare Association has been giving much importance to equip tribal youth and women with alternative skills to supplement and augment their income and employment and to fulfill the community needs with locally available raw materials and human resources towards optimum use. Some of the important skill training programmes in equipping tribal youth and women are: Tailoring, embroidery, sanitary pads, cooking snacks, painting potteries, etc Women training programmes on eco-environmental issues, socio-economic and cultural aspects have found its effect in women taking up issues affecting them, through collective action. The importance of such issues and problems are - women asserting property rights, free choice of their would be husbands, organizing women against violence on women etc. Women training programmes have been effective to a great extent and now the women sangams activities are gaining momentum with steady improvements in small savings and loan schemes with support of TWA.

The farm forestry programme helps in empowerment of women; they are benefited by the easy availability of employment during the dry season. As a result migration of women to nearby industrial towns has come down to some extent. Nurseries for supplying seedlings to farm forestry and wasteland development programme are managed and run by villagers under the guidance of village institutions (both men's and women's village institutions) are allotted to poor women of the villages. Women have gained tremendously from this minienterprise in the form of economic as well as social gains. It helps build their confidence and instill the spirit of entrepreneurial capacity in them. Two women nursery raisers from a remote tribal village participated actively and earned a lot of appreciation at a workshop held in this connection at Ahmadabad. Their knowledge of the problems and prospects of nursery rising as a profitable venture for tribal women was quite a revelation to the experts present in the workshop. Its aim was that women should involve actively in each and every stage of the farm forestry programme. 


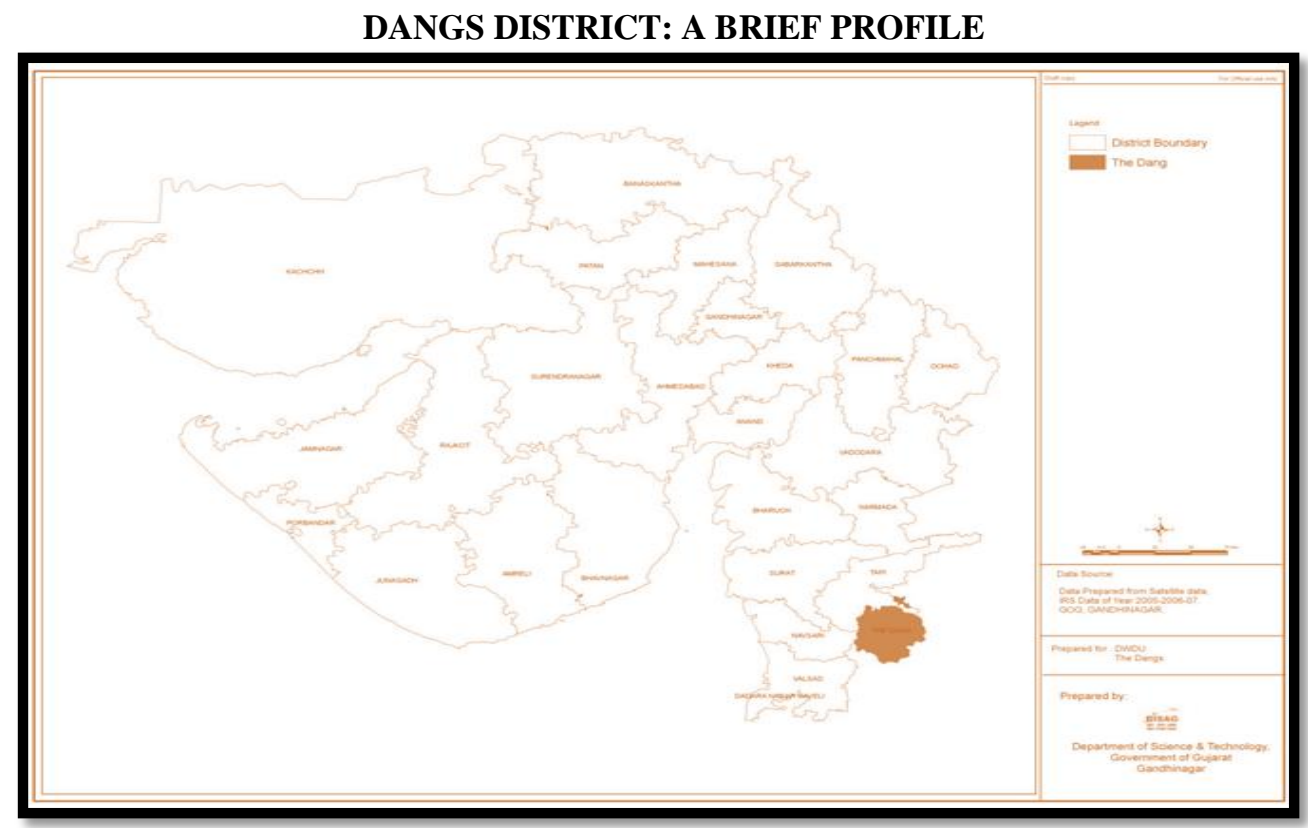

Dang (also known as The Dangs) is a district in the state of Gujarat in India. It is predominantly tribal area with sparse population and rich forest cover. The administrative headquarter/ Taluka of the district is located in Ahwa. Dangs is located in the southern part of the state. To the north and west lie Surat and Navsari districts whereas to its east and south are the districts of Maharashtra. It lies between 20.39 degree to 21.5 degree North latitudes and 72.29 degree to 73.51 degree East longitudes. It is comprised of 311 villages and has an area of 1764 sq. km.

\begin{tabular}{|c|c|}
\hline \multicolumn{2}{|c|}{ he Dangs District rural Population 2011} \\
\hline Description & Rural \\
\hline Population (\%) & $89.11 \%$ \\
\hline Total Population & 202,074 \\
\hline Male Population & 100,868 \\
\hline Female Population & 101,206 \\
\hline Sex Ratio & 1003 \\
\hline Child Sex Ratio (0-6) & 965 \\
\hline Child Population (0-6) & 36,696 \\
\hline Male Child(0-6) & 18,672 \\
\hline $\begin{array}{l}\text { Female Child } \\
\text { Percentage }\end{array}$ & $17.81 \%$ \\
\hline Literates & 124,229 \\
\hline Male Literates & 68,869 \\
\hline Female Literates & 55,360 \\
\hline Average Literacy & $75.12 \%$ \\
\hline Male Literacy & $83.79 \%$ \\
\hline Female Literacy & $66.55 \%$ \\
\hline
\end{tabular}

Source: Census survey 2011.

The total population is 226,769 as per provisional figures of Census 2011 compared to 186,792 in 2001. The Dangs district population constitutes $0.38 \%$ of Gujarat's population. It is totally a Scheduled Tribe [ST] area; about 94\% populations in the district are Scheduled Tribe. The sex ratio of girls per 1000 boys was recorded as 1003 i.e. an increase of 20 points from the 2001 Census which puts it at 945.

In education, the Dangs district has an average literacy rate of $76.8 \%$. Male and female literacy were 84.98 and $68.75 \%$ respectively. About every village has a primary school. Dangs district has secured 14th rank in overall literacy rate with $76.80 \%$ out of 26 districts in Gujarat. Gandhinagar is on top with the male literacy rate at $93.59 \%$ and Surat has 1 st position in the female literacy rate with $81.0 \%$. The Dangs rank is 15 th in male literacy rate $(84.98 \%)$ and 12 th in female literacy $(68.75 \%)$ out of 26 districts in Gujarat. 
Dangs is one of the two districts in the country having more than $80 \%$ rich forest-cover. With very small and uneconomic holdings, the majority of the cultivators barely manage to survive for few months of the year on the crops harvested. The agricultural laborers find some employment only during the agricultural season. Large numbers migrate in semi-bonded conditions to Surat district to work as cane-cutters in the sugar co-operatives.

Table 1.2 Tribal groups of the Dangs

\begin{tabular}{|lc|}
\hline Tribe & Percentage of population \\
\hline Konkana & $51.0 \%$ \\
\hline Bhil & $25.8 \%$ \\
\hline Varli & $14.7 \%$ \\
\hline $\begin{array}{l}\text { Others (Kotwalia, } \\
\text { Kathodi, etc.) }\end{array}$ & $8.5 \%$ \\
\hline
\end{tabular}

(Source: District census 2001)

The entire district is tribal dominated with $98 \%$ of the population comprised of tribals. Of the total population, $73.84 \%$ falls in the BPL category. Although the district is mainly inhabited by 13 different tribes, about two third of the tribal population consist of Konkana and Bhil. There are three ethnic tribes identified as Primitive Tribe Group (PTG) also residing in the district: the Kotwalia, Kathodi and Kolcha. This paper brings out the cases of successful tribal women belonging Bhil tribe. The training received by these women and the positive educational and economical changes that has happened to them after undergoing the training and developing skills for their livelihood.

\section{Social Structure of Bhils in Dangs district.}

Bhil tribe is a homogeneous group with their own leadership, laws and customs. Bhils are the original inhabitants of this area, at one time they were organized under a powerful chief. Under the system of chiefdom, Bhils were not subjected to elaborate system of administration but they were socially economically and politically autonomous. They led a nomadic life and were dependent on hunting and agriculture. They worship various spirits which according to their belief inhabit their villages and forests. Most of them have no land, and whoever has, manage to get a crop in a year, i.e. the monsoon crop. The vast majority of the population is made up of landless poor and unskilled people who have few opportunities for full-time employment. Villagers work the land, owned by a handful of upper caste families. As agricultural activity is seasonal and ceases in the winter months the employees are underemployed. Hence many of them switch over for a living to subsistence farming around their homes and are involved in local trade that is generally not profitable. They belong to many of the lower castes and tribes that are categorized by the Indian Government as 'Other Backward Classes' (OBC). Development of the region is possible if the women were uplifted and could contribute to the success of their family and community. The effect of empowerment of women creates a powerful influence on the norms, values and finally the laws that govern these communities (Page and Czuba, 1999).

\section{Challenges and Winds of Change}

The first and foremost challenge to the Bhil (tribe) of Dangs district is that they are still not much exposed to the outside world and are confined to their community only. Therefore living in their cocoon only and thus has witnessed hardly any socio cultural encounters. Their entire universe hence is their own community, and by virtue of this scenario, social mobility, occupational diversity, poverty alleviation, change and development, change in mindset, education and economic prosperity are still new concepts for them amidst their own traditional setup that has not altered sufficiently till the recent past.

The changes taking place in the field of science and technology,development,etc, are laying their impact on the Indian society and the feeble winds of change have started laying their influences on the Dangs tribal's as well .The educated community leaders of Bhils are seriously concerned about the educational and economic development of their community. If we closely analyze functioning of educated tribal's, we notice two traits of transformation. One group of educated tribal argues that tribal's should reform themselves with the mainstream society. The other group of tribal's wants to maintain its tribal identity. Recently the tribal's of Dangs have shown a lot of change in their outlook to cherish educational development programmes carried out in their areas. Their children definitely get encouraged to join the boarding schools. The girls are doing much better in the field of education.

\section{Skill Development Initiatives}

There are many governmental agencies, non governmental agencies (specially the Christian missionaries and Hindu groups) and the corporate sector that are working for the upliftment of the area. The goal of corporate social responsibility (CSR) is to embrace responsibility and encourage a positive impact 
through its activities on the environment, consumers, employees, communities, stakeholders and all other members of the public sphere. Furthermore, CSR-focused businesses would proactively promote the public interest by encouraging community growth and development. In this paper we seek to explore how the Corporate Social Responsibility undertaken by the Bank of Baroda has been successful in the empowerment of rural women living in highly patriarchal and traditional societies. Bank of Baroda has a training centre at Ahwa and it offers Training to the tribal's of this district. Tribals from different villages come to this training centre at Ahwa and avail of all the facilities provided by the Training institute.

Bank of Baroda (BOB) founded by The Maharaja of Baroda, Sir Sayajirao Gaekwad III, on 20 July 1908 in the princely state of Baroda in Gujarat. It is the third largest bank in India. The bank, along with 13 other major commercial banks of India, was nationalized on 19 July 1969, by the government of India. Baroda Grameen Para marsh Kendra ${ }^{3}$ (BGPK) - is another initiative undertaken by the Bank to help the rural community by providing Credit Counseling, financial literacy and other services like information on the prices of agricultural products, scientific farming, etc. It has established 52 BGPKs in 2010. Yet another initiative is the establishment of Baroda Swarozgar Vikas Sansthan ${ }^{4}$ (BSVS) for imparting free training to unemployed youth for gaining self-employment and entrepreneurship skill so that they can help improve their family's economic status and thus give a boost to the local economic status in those locations. Till now 25 (BSVS) have been established by the Bank in which more than 37,000 youth have been trained and around 22,000 have gained self-employment. Furthermore, a special thrust is laid by the Bank in financing SC/ST under various government sponsored schemes namely Swaranjayanti Gram Swarojgar Yojana (SGSY), Swarna Jayanti Shahar RojgarYojana (SJSRY), Prime Minister Employment Generation Programme (PMEGP), etc.

Under the guidance Bank of Baroda, Krushi Vigyan Kendra, Waghai (Dangs district) provides extension services in the district. It also plans and conducts need based production oriented short duration courses for farmers, farm women and rural youth and imparts vocational training to un-employed rural youths and school dropouts for the self-employment. It has developed and maintained instructional farm and demonstration unit (vermin compost) for training purpose. The bank organizes Extension activities between scientists and youth which include frontline demonstration, Vocational training, Krushimela, Khedut Shibir, Training (on Campus) Field training (off Campus) Agricultural exhibition etc. A few NGOs in the district are also providing extension services.

The agro- climatic conditions prevailing in the district are suitable for cultivation of fruits like Mango, Cashew, Banana, Custard Apple (Sitaphal), Sapota (Chikoo), Aonla, Lime, and vegetables like Potato, Onion, Brinjal, Ladies finger, Carrots etc. There is a Govt. Medicinal plants collection centre in the district. The raw materials for different medicines are collected at the Govt. centre. So short duration training is given by the different departments of the government. Over 1000 women have been trained in the making of Nagli papadi and other Nagli preparations by NGOs and TDO under RSVY programme. The activity is mostly under taken on group basis by Self Help Groups (SHG) Around 100 SHGs are engaged in the activity. The existing SSI units mainly engaged in activities like garments manufacturing, wood work, bamboo craft, cane work, paper \& paper mash, metal work, maintenance and repair works of electrical machinery / oil engines / transport vehicles, etc. All the youth trained under various training programs under Capacity Building Component of RSVY should be provided guidance and sponsorship for establishing their own units under various trades / skills learnt by them. The training given by these institutions is not enough as the population of Dangs 7.5 million people, so there is a need based training and collaboration with other departments and agencies.

In the district of Dangs in Gujarat, Bank of Baroda with its head office and training centre at Ahwa has been working for the development of the tribals. Training to youth in different areas are given based on the availability of where job opportunities. The training needs are also consulted with the village community. The trainings are either given at the centre or in their villages depending upon the program. The programs are fully financed and the trainees are provided with all the basic facilities. After the training the feed- back also is taken. A helping hand is rendered even after completion of the programs.

The main focus of this paper is on the training received by the tribal Bhil women in the Dangs district. The following table shows the different programs conducted by BSVS - Ahwa. It gives the picture of the training programs, number of participants, and duration.

\footnotetext{
${ }^{3}$ Baroda grameen para marsh Kendra is counseling provided by the Bank officials to the tribal and rural youth.

${ }^{4}$ Baroda swarozgae vikas sansthan is a Scheme that covers all aspect of self- employment like capacity building, subsidy, infrastructure facility, credit, skill up gradation, insurance and marketing.
} 
Table-1: Training programme for the Tribal (Bhil) Women of Dangs District

\begin{tabular}{|l|l|l|l|l|}
\hline Batch No. & Name of Training & Village & Duration & Total No. Trainees \\
\hline $\mathbf{1}$ & Cooking & Ahwa & 4 weeks & $\mathbf{2 5}$ \\
\hline $\mathbf{2}$ & Incense stick making & Vangan & 2 weeks & $\mathbf{3 4}$ \\
\hline $\mathbf{3}$ & Sanitary pad making & Ahwa & 3 weeks & $\mathbf{2 5}$ \\
\hline $\mathbf{4}$ & Farm forestry & Borkhet & 1 month & $\mathbf{1 5}$ \\
\hline $\mathbf{6}$ & Stitching & Koshimda & $\mathbf{2}$ weeks & $\mathbf{1 8}$ \\
\hline $\mathbf{7}$ & Organic food & Godadia & $\mathbf{3}$ weeks & $\mathbf{2 2}$ \\
\hline $\mathbf{8}$ & Pashupalan & Kakshala & $\mathbf{3}$ weeks & $\mathbf{2 1}$ \\
\hline $\mathbf{9}$ & Cooking & Gadvihir & $\mathbf{2}$ weeks & $\mathbf{1 3}$ \\
\hline $\mathbf{1 0}$ & Snack making & Nimpada & 1 week & $\mathbf{1 5}$ \\
\hline $\mathbf{1 1}$ & Pashupalan & Mahalpada & $\mathbf{3}$ days & $\mathbf{1 5}$ \\
\hline $\mathbf{1 2}$ & Snack making & Subir & $\mathbf{3}$ weeks & $\mathbf{2 2}$ \\
\hline $\mathbf{1 3}$ & Stitching & Kakshala & $\mathbf{4}$ weeks & $\mathbf{2 1}$ \\
\hline $\mathbf{1 4}$ & Stitching/Sewing & Gadhav & $\mathbf{2}$ weeks & $\mathbf{1 3}$ \\
\hline & Pashupalan & Kutarna Chya & 1 week & $\mathbf{1 5}$ \\
\hline
\end{tabular}

Source: Annual report 2008-09 Bank of Baroda

\section{Major Effects}

- Training centre Ahwa trained altogether 274 trainees from $100 \%$ tribal Villages of Dangs District. The women's representation was 100 percent. It is not very easy for women without explicit family support to be away from their homes for relatively long periods of time. Also since women are less exposed than men, travelling to the different villages for the training workshops were a major hurdle. But still the women were successful in receiving training.

- $70 \%$ of the trainees are involved in development process: the nature of involvement depended very much on the motivation and capacity of the ex-trainees. Some are actively working as volunteers; others are working in their individual capacity in their own villages. About 10 of them are absorbed within the government structure as lower level functionaries

- Increased efficiency in literacy levels of all those who went through the training process. This was evident from the nature of presentations made when they were called upon to do so during the workshops. This was also clear from their increased capacity to read materials and write reports in the local language by the end of the training programme.

- Facilitation of networking among the tribal women and solidarity development as they interact with each other on several platforms.

\section{Success Stories}

CASE-1:Village Ghadhav

\section{Empowerment Through Stitching and Papad Making}

Tallika (name changed), 19, is a resident of Ahwa village. She belongs to a tribal family. She belonged to a very poor family and depends on daily wages for livelihood. She is now a mother of an illegitimate baby girl born out of her love affair with a tribal boy, who impregnated her but never married. Her teen age pregnancy dragged the whole family in mud and even villagers excommunicated with the family. She was abandoned by her family but she gave birth to her fatherless child, because of her decision her whole family was asked to go out of the village, somehow the family managed to stay in the outskirts of the village.

Tallika joined the training institute and learnt sewing and stitching in the training programme organized by the Bank of Baroda in Ghadav. She underwent a 48 day training where the group of trainees not only learnt the skill of stitching and tailoring but communication, marketing and decision making skills also. Focusing on individual development the institution also offered as a part of the training module topics like personal hygiene and sanitation, stress management and interpersonal relationships. The Bank of Baroda distributed sewing machines to all the women who successfully completed their 48 days training to start their livelihood.

Tallika earned her living by stitching blouses and frocks for the tribal women and children. She also learnt the Papad making from the locally available product nagli. She with the help of three other friends tried to convince other women of her village to join the training institute and earn some money for their living. They were successful in it and today under their guidance total 10 SHGs are formed. This has brought a change in lives of these women today there are economically independent. This comprehensive training increased the confidence of these women and immediately after completing the course, they started a small tailoring unit. She shared that villagers from the nearby areas also come to get their clothes stitched with them. She expressed her happiness and said she feels empowered and confident. They are now proud to be able to stand on their feet. As people in the area celebrate Tribal fare in a big way, these women got good offers for 
stitching clothes and their skill and adherence to time pleased the people of the area so their business improved within no time. In just two months they were able to do a business worth Rs 15,000 which increased their confidence. Recently, the two tribal welfare residential schools of that area agreed to give them orders for stitching the school uniforms for 600 children. This is how this poor tribal girl is now economically independent to educate her girl child.

\begin{tabular}{|c|c|}
\hline & $\begin{array}{c}\text { CASE-2: Village Borkhet } \\
\text { Empowerment Through Farm Forestry }\end{array}$ \\
\hline & 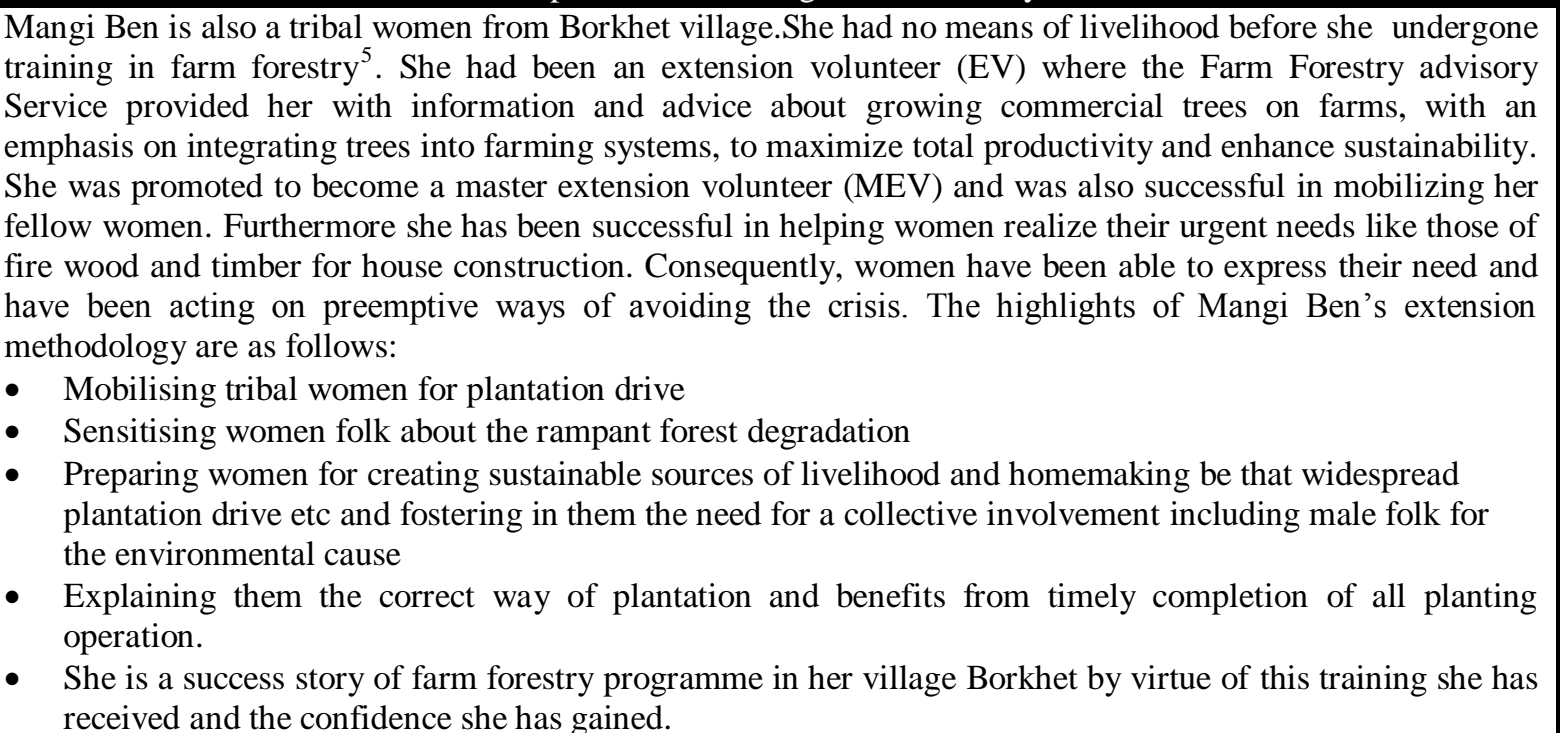 \\
\hline
\end{tabular}

\section{Assessment and Impact}

The monitoring of Skill Training Programmes is organized mainly by the following means:

(a) Quarterly and Annual reports from the Workshop organizers

(b) Periodical visits of officers from the Bank and their reports

(c) Meetings with the training organizers at regular intervals

Evaluation is a process wider than monitoring and its purpose is not only to improve the process of implementation, but also to review the very design of the programme in order to achieve its objectives. It should be carried out through an external agency and all the stakeholders should be associated "Improving the Skills and Productivity of the tribal women. Thus, assessment of these activities would help the trainees to improve and work with perfection. It will lead to better productivity and income of these tribal's.

\section{Suggestive rectification}

- To consider tribal women not only as employee but as potential contributors to the growth of the region, community and economy of Gujarat.

- To engage women in income generating activities in home based or village based industries.

- The trade should be innovative and strategic in promoting activities where larger share is received by tribal women.

- Emphasis should be given to Women Friendly Special Projects to promote

- To facilitate participation in productive work that ultimately leads to increase in social empowerment of woman.

- Farm forestry should be implemented through Mahila Vikas Mandal (MVM)

Thus, there is no doubt that the rural women can acquire any developmental milestones (skills) only through education and thus can change their own destiny. Their self perception can be elevated by the knowledge that they are contributing financially and visibly to the household and that they are in a better negotiating position. They can avoid dependence on others and escape exploitation in everyday life, avoid humiliation, gain confidence to work more productively. Thus, education has played a major role in

\footnotetext{
${ }^{5}$ Farm forestry includes any trees on farm land which are managed to produce saleable products such as timber, oil, tannin, charcoal or carbon credits.
} 
empowering rural women. They contribute towards national development by making $36 \%$ of the GNP exclusive of their services as mothers and household managers.

\section{Conclusion}

Any developmental process is the expansion of assets and capabilities of rural women to participate in, negotiate with, influence, control, and hold the institution accountable that affect their lives. Skill development among rural women is the need of the hour so as to make them confident, self reliant and to develop in them the ability to be a part of decision making at home and outside. Indeed it may not be wrong to say that still tribal's and rural women are the most disadvantaged and neglected section of the society for they are economically backward. Therefore there is a need on the part of the government and civil society to enable improvement in the quality of life of such vulnerable sections of the Indian population.

More importantly the developmental process in India should give priority to welfare schemes and programmes meant for scheduled castes and scheduled tribes' including women. These are the people who are economically backward; therefore, there is a need for sincere efforts on the part of the government to help improve the quality their of life. The Social Assessment for the training and skill development clearly reflected that rural landless (mostly SC's and ST's) form an integral part of poverty-ridden and marginalized groups. By empowering rural woman through education can thus enable them to live with dignity and self reliance cutting across the barriers of customary biases and prejudices, social barrier of caste, class, gender, occupation and institutional barriers that prevent them from taking actions to improve their state both at the individual and collective level. Therefore, free education and necessary and employable skill development programmes must be launched for tribal students and women so as to make them self reliant and economically independent. Furthermore, right to vote is meaningless unless rural women are made aware, educated and imparted skills to understand the order of the day and this can bring change in their lives, in the family and lastly transform the holistic tribal landscape of India, through education, legal awareness, and socio economic independence.

\section{References}

[1] Atchoarena, D. \& Gasperini, L. (2003). Education for rural development: towards new policy responses. FAO, UNESCO.

[2] Baumann.P \& Sinha.S (2001): Linking Development with Democratic Processes in India: Political Capital and Sustainable Livelihoods Analysis: Natural Resource Perspectives, Number 68, June 2001. The Overseas Development Institute, 111 Westminster Bridge Road, London SE1 7JD, UK.

[3] Corporate Social Responsibility (CSR) N Annual Report of Bank of Baroda

[4] Corporate social Responsibility, Wikipedia, the free encyclopedia

[5] Empowering the Scheduled Tribes, Report of The Steering Committee On For The Tenth Five Year Plan (2002-2007), Planning Commission, Government of India New Delhi, October -2001

[6] Eleventh Five Year Plan, Volume I, II, and III, Planning Commission, Government of India, Yojana Bhawan, SansadMarg, New Delhi

[7] Edward Freeman, Strategic management: a stakeholder approach in 1984.

[8] Freeman R, Strategic Management: stakeholder approach (Pitman1984) ISBN 9780273019138 ,

[9] Guidelines on the use of Consultants, (2006) Asian Development Bank. Guidelines for Skill Training Projects

[10] Gujarat Infrastructure Development (Amendment) Act, (2006)

[11] Government of India, Ministry of Human Resource Management (1952): Report of Secondary Education Commission (1952-53). New Delhi.

[12] Government of India, Ministry of Human Resource Management (2006): Selected educational Statistics, 2003-04, New Delhi.

[13] Page.N \& C.E.Czuba (1999) “Empowerment: What is it?” Journal of Extension, vol.37, No.5

[14] Potential Linked Credit Plans (PLPs) 2010-2011: A Report of the Ahmadabad Regional Office of the National Bank for Agriculture and Rural Development

[15] Moser, C. (1989), Gender planning in the third world: Meeting practical and strategic gender needs, World Development 17 (11), Pages 1799-1825Ryan, Paul. 2001a. "The School-to Work Transition: A Cross-National Perspective." Journal of Economic Literature Vol. XXXIX, March: 34-92.

[16] Report of the Working Group on Skill Development and Vocational Training, Government of India, Planning Commission

[17] Study conducted by FAO and UNESCO: Education for rural development: towards new policy responses co-ordinated and edited by David Atchoarena, Lavinia Gasperini, and UNESCO Publications

[18] The World Bank, FAO, IFAD, (2008) Gender and Rural Micro Finance: Reaching and empowering Women, Guide for practitioners. Module 3

[19] The Ministry of Tribal Affairs, Annual Report (2006-07)

[20] Vocational Training Centre in Tribal Areas, Ministry of Tribal Affairs, Government of India, New Delhi.

[21] World Bank Group study: 2003 Public Policy for Corporate Social Responsibility Edited by Djordjija Petkoski World Bank Institute and Nigel Twose World Bank Group

Internet Sources:

[22] http://tribal.gov.in/ , Retrieved on 03 Apr 2010.

[23] http://planningcommission.gov.in,Retrieved on 03 Apr 2010

[24] http://vanbandhukalyanyojana.gujarat.gov.in/, Retrieved on 24 may 2010

[25] http://www.dhruva.org.in/New\%20Doc/Wadi\%20Based\%20Livelihood\%20Development\%20Programme\%202.pdf ,Retrieved on 05 June 2010

[26] http://www.nabard.org, Retrieved on 02 Aug 2010

[27] http://www.dise.in/Downloads/Publications/Publications\%202009 10/Flash\%20Statistics\%202009-10.pdf ,Retrieved on 06 Feb 2011

[28] www.vanbandhukalyanyojana.gujarat.gov.in, Retrieved on 11 Feb 2011 